\title{
NANOPRTICLES OF METALS AND THEIR INORGANIC COMPOUNDS OBTAINED THROUGH INTERPHASE AND REDOX-TRANSMETALATION INTERACTION: APPLICATION IN MEDICINE AND PHARMACOLOGY
}

Vorobyova $\mathrm{SA}^{1} \otimes{\text {, Rzheussky } \mathrm{SE}^{2}}^{2}$

${ }^{1}$ Research Institute for Physical Chemical Problems of the Belarusian State University, Minsk, Belarus

Vitebsk State Order Of Peoples' Friendship Medical University, Vitebsk, Belarus

\begin{abstract}
Synthesis of nanoparticles of metals and their compounds with given morphology and dispersity for use in medicine, pharmacology, microelectronics, as well as subsequent research of their properties, is one of the current problems in the field of preparative inorganic chemistry. Interphase synthesis and redox-transmetalation interaction are as promising as the traditional precipitation from aqueous solutions, but not as researched. This study presents the results of a physicochemical analysis of nanoparticles of metals and their compounds obtained through chemical precipitation from aqueous solutions, interphase and redox-transmetalation interactions. Data describing the influence of phase composition and dispersity of copper and copper oxide (II) nanoparticles on their antimicrobial properties, as well as the results of researching the possibility to use magnetite magnetic fluids for mesenchymal stem cells marking, illustrate the application options synthesized nanoparticles find in pharmacology and medicine.
\end{abstract}

Keywords: nanomedicine, pharmacology, nanometals, oxides, sulfides, magnetic fluids, stem cells, antimicrobial agents Funding: experimental stages of the study were supported by the Belarusian Republican Foundation for Fundamental Research (grants X96-157, X04-073, X09025, X11MS-034).

Acknowledgments: the authors would like to thank N. P. Drazhina and E. A. Petrova for researching the marked mesenchymal stem cells, and fellows of the Laboratory of Condensed Matter Chemistry at the Research Institute for Chemical Physical Problems of the Belarusian State University who participated in the synthesis and research of nanoparticles of metals and their compounds.

$\triangle$ Correspondence should be addressed: Svetlana A. Vorobyova Leningradskaya 14, Minsk, Belarus, 220030; vorobyova@bsu.by

Received: 27.06.2018 Accepted: 28.07.2018

DOI: $10.24075 /$ brsmu.2018.076

\section{ПРИМЕНЕНИЕ В НАНОМЕДИЦИНЕ И ФАРМАКОЛОГИИ НАНОЧАСТИЦ МЕТАЛЛОВ И ИХ НЕОРГАНИЧЕСКИХ СОЕДИНЕНИЙ, ПОЛУЧЕННЫХ МЕЖФАЗНЫМ И КОНТАКТНЫМ ВЗАИМОДЕЙСТВИЕМ}

\author{
С. А. Воробьева ${ }^{1 凶}$, С. Э. Ржеусский ${ }^{2}$ \\ ' Научно-исследовательский институт физико-химических проблем Белорусского государственного университета, Минск, Беларусь \\ Витебский государственный ордена Дружбы народов медицинский университет, Витебск, Беларусь
}

\begin{abstract}
Одной из актуальных проблем современной препаративной неорганической химии являются получение и исследование наночастиц металлов и их соединений с заданными морфологией и дисперсностью для использования в медицине, фармакологии, микроэлектронике. Наряду с традиционным осаждением из водных растворов перспективны, но менее изучены межфазный синтез и контактное восстановление. В работе представлены результаты физико-химического исследования наночастиц металлов и их соединений, полученных химическим осаждением из водных растворов, межфазным и контактным взаимодействием. Для иллюстрации использования синтезированных наночастиц в фармакологии и медицине приведены данные по влиянию фазового состава и дисперсности наночастиц меди и оксида меди (II) на их противомикробные свойства и результаты исследования возможности применения магнетитовых магнитных жидкостей для маркирования мезенхимальных стволовых клеток.
\end{abstract}

Ключевые слова: наномедицина, фармакология, нанометаллы, оксиды, сульфиды, магнитные жидкости, стволовые клетки, антимикробные средства

Финансирование: экспериментальные исследования проводились при поддержке Белорусского республиканского фонда фундаментальных исследований (гранты X96-157, X04-073, X09-025, X11MC-034)

Благодарности: авторы благодарят Дражину Н. П и Петрову Е. А. за проведение исследований маркированных мезенхимальных стволовых клеток, а также сотрудников лаборатории химии конденсированных сред НИИ физико-химических проблем Белгосуниверситета, принимавших участие в синтезе и исследовании наноразмерных металлов и их соединений.

$\bowtie$ Для корреспонденции: Светлана Александровна Воробьева ул. Ленинградская, д. 14, г. Минск, Беларусь, 220030; vorobyova@bsu.by

Статья получена: 27.06.2018 Статья принята к печати: 28.07.2018

DOI: $10.24075 /$ vrgmu.2018.076

The problem of synthesizing nanoparticles of metals and their inorganic compounds with defined morphology and dispersity, which largely determine properties and quality of the developed advanced materials, is interesting from the scientific point of view and important from the standpoint of practicality. Therefore, the search for the new and improvement of the already known methods for obtaining nanoparticles of metals and their compounds with required properties is a standing scientific and technological challenge.

To obtain nanoscale metals and their inorganic compounds, chemists often select the traditional and thoroughly researched precipitation technique. However, interphase synthesis 
and redox-transmetalation interaction are as promising as precipitation from aqueous solutions, but not as researched. We applied the latter techniques to obtain hydro- and organosols of some metals, oxides and salts.

Data describing the influence of phase composition and dispersity of copper and copper oxide (II) nanoparticles on their antimicrobial properties, as well as the results of researching the possibility to use magnetite magnetic fluids for mesenchymal stem cells labeling, illustrate the application options synthesized nanoparticles find in pharmacology and medicine. These data and results are given below.

\section{Interphase synthesis of nanoscale metals and their inorganic compounds}

Interphase synthesis allows obtaining nanoscale metals and their compounds through interaction of reagents dissolved in different phases of aqueous-organic media; as opposed to reactions in microemulsions, the phases are not allowed to mix. These reactions can take place in one of the phases or at the interface between them; the conditions in each phase differ from each other significantly, which allows obtaining inorganic substances with properties different from those received when such substances precipitate in homogeneous media, aqueous solutions in particular [1-8].

The table below and reports [2-8] present the physicochemical properties of the organo- and hydrosols of metals and their compounds we obtained in the context of our study.

Having analyzed the routine and the results of the interphase synthesis, we found that state (sediment, film, colloidal solution) and localization (organic or aqueous phase, their interface) of the reaction products depend on many factors (composition, concentration and ratio of reagents, reaction temperature, volumes of phases, interface area); therefore, it is currently impossible to formulate the patterns of interphase synthesis common to compounds of different classes.

At the same time, the data obtained highlight some features of interphase synthesis. Firstly, it eliminates the need for additional surfactants and stabilizing additives in the composition of colloidal solutions obtained. In the context of interphase synthesis, particles of the dispersed phase of colloidal solutions appear simultaneously with surfactants (oleic acid or sodium oleate) and stabilizing additives (quaternary ammonium compounds); from this viewpoint, the process of obtaining a colloidal solution through interphase interaction can be called self-organizing, with the surfactant's concentration sufficient to synthesize a colloidal solution achieved during the synthesis process and not determined empirically, as is the case for ferromagnetic fluids synthesis.

Secondly, interphase synthesis allows obtaining inorganic substances under conditions that are significantly milder than those seen in chemical precipitation of the same substances from their aqueous solutions. As a result, a change in the composition of a two-phase system - replacing aqueous phase with alcohol phase, for example, and keeping all the other parameters unaltered, - allows synthesizing nanoparticles with different morphology and dispersity, a phenomenon we have demonstrated using zinc oxide as the subject substance [5].

In addition, introduction of a polymeric substance into one of the phases effects a virtually single-stage synthesis of nanocomposites containing nanoscale particles formed directly in the polymer matrix, which prevents their aggregation and, consequently, allows having the obtained nanoparticles highly dispersed.

Interphase synthesis also offers the opportunity to synthesize $\mathrm{Fe}_{3} \mathrm{O}_{4} / \mathrm{Au}$ and $\mathrm{Fe}_{3} \mathrm{O}_{4} / \mathrm{CdS}$ bifunctional magnetic nanoparticles that feature properties of both a magnetic core $\left(\mathrm{Fe}_{3} \mathrm{O}_{4}\right)$ and optically active shells (Au, CdS) [6-8]. Thus, we managed to obtain the $\mathrm{Fe}_{3} \mathrm{O}_{4} / \mathrm{Au}$ "core-shell" nanocomposite systems through reduction of the chloroauric acid in a twophase system with one phase being formed of a magnetite colloidal solution [8].

\section{Synthesis of bi- and trimetallic nanoparticles by redox- transmetalation}

We have also applied the redox-transmetalation process to obtain bi- and trimetallic nanoparticles (including those with "core-shell" structure); this method implies reduction of metal

Table. Results of investigation of nanoparticles of metals and their compounds obtained by interphase synthesis in a two-phase system (non-polar solvent / water)

\begin{tabular}{|c|c|c|c|c|}
\hline Colloidal dispersity & Reaction products localization phase & Average particle size, $\mathrm{nm}$ & $\begin{array}{l}\text { UV-vis adsoption maximum } \\
\lambda_{\text {max }}, \mathrm{nm}\end{array}$ & Reference \\
\hline $\mathrm{Au}$ & $\begin{array}{c}\text { Organic, water or interface } \\
\text { (determined by synthesis conditions) }\end{array}$ & 2.6 & 514 & 2 \\
\hline $\mathrm{Ag}$ & Organic & 10.0 & 440 & 3 \\
\hline $\mathrm{Pd}$ & Organic & 1.4 & 440 & - \\
\hline $\mathrm{Ag} / \mathrm{Pd}$ & Organic & 2.1 & 430 & - \\
\hline $\mathrm{Ag} / \mathrm{Au}$ & $\begin{array}{c}\text { Organic, water or interface } \\
\text { (determined by synthesis conditions) }\end{array}$ & 4.2 & 470 & - \\
\hline $\mathrm{Cu}$ & $\begin{array}{l}\text { Organic or water (determined by } \\
\text { synthesis conditions) }\end{array}$ & 10.0 & 575 & - \\
\hline $\mathrm{CuO}$ & Organic & 3.2 & - & 4 \\
\hline $\mathrm{ZnO}$ & $\begin{array}{l}\text { Organic or water (determined by } \\
\text { synthesis conditions) }\end{array}$ & $\begin{array}{l}\text { Particle size and shape depend on } \\
\text { the conditions of the synthesis }\end{array}$ & - & 5 \\
\hline CdS & Organic & 2.0 & 311 & 7 \\
\hline Cus & Organic & $\begin{array}{l}\text { Particle size and shape depend on } \\
\text { the conditions of the synthesis }\end{array}$ & - & - \\
\hline $\mathrm{ZnS}$ & Organic & $\begin{array}{l}\text { Particle size and shape depend on } \\
\text { the conditions of the synthesis }\end{array}$ & - & - \\
\hline $\mathrm{Fe}_{3} \mathrm{O}_{4} / \mathrm{Au}$ & Organic & 12.8 & 590 & 6 \\
\hline $\mathrm{Fe}_{3} \mathrm{O}_{4} / \mathrm{CdS}$ & Organic & 10.3 & 311 & 7 \\
\hline
\end{tabular}


salts with metal nanoparticles that form the core [9]. Compared to the "core-shell" composite synthesis methods that involve linkers, redox-transmetalation is relatively simple to apply in the context of experiments and does not require the use of expensive reagents for surface functionalization.

Making use of the redox-transmetalation method, we have obtained and thoroughly researched bi- and trimetallic nanoparticles with metallic copper and magnetic Fe and FeCo nanoparticles as core (reducing agent). According to our findings contact reduction of gold and silver compounds with FeCo nanoparticles produces FeCoAu and FeCoAg magnetic nanoparticles with a "core-shell" structure [10]. The precious metal shells that form on the surface of the easily oxidized magnetic nuclei prevent or reduce the degree of their oxidation; in addition, it makes the resulting nanocomposites more diverse in terms of directed functionalization, thus extending their applicability to cover biomedicine, among other fields.

\section{Effect of dispersity and phase composition on antimicrobial properties of cupriferous antimicrobial agents}

In the field of the new antimicrobial drugs, a promising trend is enriching them with low-toxic metal nanoparticles that cause no resistance response and offer pronounced bactericidal, antiviral, fungicidal and immunomodulatory potency.

As a rule, when using nanometals as a pharmaceutical substance, the designers seek to have the particles as disperse as possible and neglect the costs of development and technological adaptation of the superfine particles synthesis methods, which can be considerably greater than the effect form application of those particles. In this connection, we investigated the effect phase composition has on the antimicrobial potency, morphology and dispersity of metallic copper and copper (II) oxide nanoparticles obtained through chemical precipitation from aqueous solutions with polyethylene glycol [11].

The sample preparation technique and the results of the study of antimicrobial potency and range of the nanoparticles obtained were described in detail earlier [12]. Gram-negative (Escherichia coli), gram-positive (Pseudomonas aeruginosa, Staphylococcus aureus), spore-forming (Bacillus subtilis) bacteria and microscopic fungi (Candida albicans) were used as test cultures. The control treatments were ointments containing chloramphenicol, chlorhexidine and the combination of choline salicylate and cetalconium chloride.

The study revealed that copper nanoparticles can suppress a wide range of gram-positive and gram-negative bacteria, but their antimicrobial effect is less pronounced than that of ointment containing chloramphenicol. At the same time, the antifungal properties of copper nanoparticles are only marginally inferior to those of drugs containing chlorhexidine, choline salicylate and cetalconium chloride.

Having analyzed the dependence of antimicrobial effect on size we learned that the antimicrobial potency of copper nanoparticles, which vary in size from 14 to $37 \mathrm{~nm}$, grows linearly as the size decreases to $14 \mathrm{~nm}$. The findings describe copper-containing suspension the concentration of which does not exceed $0.5 \%$ wt.; when the concentration is $0.75 \%$ wt., antimicrobial potency of copper nanoparticles in such a suspension does not increase with the size of particles going down from $37 \mathrm{~nm}$ to $14 \mathrm{~nm}$.

\section{Using magnetic nanoparticles for MSC labeling}

The options of application of magnetic nanoparticles for mesenchymal stem cells (MSCs) labeling is one of the projects part of the magnetite magnetic fluids research effort undertaken at the Research Institute for Physical Chemical Problems of the Belarusian State University, where such fluids were synthesized. Fellows from the Belarusian State Medical University (Minsk, Belarus) participated in the project. For nanomedicine, the most promising magnetic nanoparticles are nanosized iron (II, III) oxides. They are simple to synthesize and their cytotoxicity level is low [13]. It is known that magnetic nanoparticles can be used for labeling both mesenchymal and neural stem cells with the aim to isolate them in cell suspension [14-16], as well as to concentrate [17] and to enable MRI visualization [18], which is especially valuable when stem cell are transplanted [19].

The synthesis of magnetic nanoparticles, MSC labeling and corresponding research results are detailed in the reports [20, 21]. MSC cultures isolated from the bone marrow of sexually mature white outbred rats were used for the purposes of MSC labeling. Magnetic iron (II, III) oxide nanoparticles were obtained through chemical precipitation from aqueous solutions followed by stabilization by surfactants.

The results of the study prove that the synthesized magnetic nanoparticles, after 24 hours of incubation and at $0.0069 \%$ wt., are lowly cytotoxic and can effectively mark MSCs. The findings suggest that magnetic nanoparticles localize in vesicles of the cells' cytoplasm and remain there when replanted; they do not hinder the cells' ability to adhere, spread and proliferate. When the cells divide, magnetic nanoparticles get distributed between daughter cells. It was experimentally confirmed that stem cells labeled with magnetic nanoparticles can be detected in vivo by MRI.

It should also be noted that the obtained magnetic nanoparticles, stabilized by oleic acid and triethanolamine, have several advantages over the known materials based on nanoscale iron oxides, which require prolonged incubation with stem cells or additional transporters (e.g., protamine sulfate) and negatively affect the ability of stem cells to differentiate.

\section{CONCLUSION}

Despite the significant progress in the development and research of nanoscale metals, oxides and salts synthesis, their application as part of nanocomposite materials designed for various purposes requires joint effort of scientists from various research fields. With regard to nanomedicine and pharmacology, it is crucial to learn to define the morphology, dispersity and phase composition of the nanoparticles used in order to meet the requirements for the developed medical materials and to assess the risks of their practical use.

\section{References}

1. Xinkui Yangying, Chen Wang. A new two-phase system for the preparation of nearly monodisperse silver nanoparticles Materials Letters. 2008; (62): 4366-8. DOI: 10.1016/j. matlet.2008.07.034
2. Vorobyova SA, Sobal NS, Lesnikovich Al. Colloidal gold, prepared by interphase reduction. Colloids and Surfaces A: Physicochem Eng Aspects. 2001; (176): 273-7.

3. Lesnikovich Al, Vorobyova SA, Sobal NS. Preparation of silver 
nanoparticles by interphase reduction. Colloids and Surfaces $A$ : Physicochem Eng Aspects. 1999; (152): 375-9.

4. Vorobyova SA, Lesnikovich Al, Mushinskii W. Interphase synthesis and characterization of $\mathrm{CuO}$ in octane. Colloids and Surfaces A: Physicochem Eng Aspects. 1999; (150): 297-300.

5. Vorobyova SA, Lesnikovich Al, Mushinskii W. Interphase synthesis and characterization of zinc oxide. Materials Letters. 2004; (58): 863-6. DOI: 10.1016/..matlet.2003.08.008.

6. Semenova EM, Vorobyova SA, Lesnikovich Al, Fedotova JA, Bayev VG. Fabrication and investigation of magnetite nanoparticles with gold shell. Journal of Alloys and Compounds. 2012; (530): 97-101. DOI: 10.1016/j.jallcom.2012.03.090.

7. Semenova EM, Vorobyova SA, Lesnikovich Al. Synthesis of cadmium sulfide coated magnetic nanoparticles. Physics, Chemistry and Application of Nanostructures: Proceeding of the International Conference. Nanomeeting-2011; 2011 May; Minsk, Belarus. 333-336.

8. Semenova EM, Vorobyova SA, Lesnikovich Al. Interphase synthesis of $\mathrm{Fe}_{3} \mathrm{O}_{4} / \mathrm{CdS}$ core-shell nanoparticles. Optical Materials. 2011; (34): 99-102. DOI: 10.1016/j.optmat.07.008.

9. Lee W, Kim M, Choi J, Park J. Redox-transmetalation process as a generalized strategy for core-shell magnetic nanoparticles. J Amer Chem Soc. 2005; (127): 16090-7. DOI: 10.1021/ ja053659j.

10. Bayev VG, Fedotova JA, Vorobyova SA, Svito IA, Ivashkevich OA, Tyutyunnikov SI, Kolobylina NN, Guryeva PV. Mössbauer spectroscopy and magnetometry of FeCo-Ag and FeCo-Au nanocomposites synthesized by a redox-transmetalation method. Materials Chemistry and Physics. 2018; (216): 349-53. DOI: 10.1016/j.matchemphys.2018.06.031.

11. Auchynnikava AA, Vorobyova SA, Rzheussky SE. Antimicrobial activity of copper nanoparticles depending on the particles size. Physics, Chemistry and Application of Nanostructures: Proceeding of the International Conference. Nanomeeting-2015; 2015 May; Minsk, Belarus. 480-3.

12. Rzheusskij SJe, Avchinnikova EA, Vorobyova SA. Nanodiagnostika i antimikrobnye svojstva nanochastic medi. Vestnik farmacii. 2014; (3): $62-8$.

\section{Литература}

1. Xinkui Yangying, Chen Wang. A new two-phase system for the preparation of nearly monodisperse silver nanoparticles Materials Letters. 2008; (62): 4366-8. DOI: 10.1016/j. matlet.2008.07.034.

2. Vorobyova SA, Sobal NS, Lesnikovich Al. Colloidal gold, prepared by interphase reduction. Colloids and Surfaces A: Physicochem Eng Aspects. 2001; (176): 273-7.

3. Lesnikovich Al, Vorobyova SA, Sobal NS. Preparation of silver nanoparticles by interphase reduction. Colloids and Surfaces A: Physicochem Eng Aspects. 1999; (152): 375-9.

4. Vorobyova SA, Lesnikovich Al, Mushinskii W. Interphase synthesis and characterization of $\mathrm{CuO}$ in octane. Colloids and Surfaces $\mathrm{A}$ Physicochem Eng Aspects. 1999; (150): 297-300.

5. Vorobyova SA, Lesnikovich Al, Mushinskii W. Interphase synthesis and characterization of zinc oxide. Materials Letters. 2004; (58): 863-6. DOI: 10.1016/j.matlet.2003.08.008.

6. Semenova EM, Vorobyova SA, Lesnikovich Al, Fedotova JA, Bayev VG. Fabrication and investigation of magnetite nanoparticles with gold shell. Journal of Alloys and Compounds. 2012; (530): 97-101. DOI: 10.1016/j.jallcom.2012.03.090.

7. Semenova EM, Vorobyova SA, Lesnikovich Al. Synthesis of cadmium sulfide coated magnetic nanoparticles. Physics, Chemistry and Application of Nanostructures: Proceeding of the International Conference. Nanomeeting-2011; 2011 May; Minsk, Belarus. 333-336.

8. Semenova EM, Vorobyova SA, Lesnikovich Al. Interphase synthesis of $\mathrm{Fe}_{3} \mathrm{O}_{4} / \mathrm{CdS}$ core-shell nanoparticles. Optical Materials. 2011; (34): 99-102. DOI: 10.1016/j.optmat.07.008

9. Lee W, Kim M, Choi J, Park J. Redox-transmetalation process as a generalized strategy for core-shell magnetic nanoparticles. $J$
13. Cen L, Neoh KG, Sun J, Hu F et al. Labeling of Adipose Derived Stem Cells by Oleic Acid Modified Magnetic Nanoparticles. Adv Funct Mater. 2009; (8): 1158-66. DOI: 10.1002/adfm.200801670.

14. Wang L, Neoh K-G, Kang E-T et al. Biodegradable magneticfluorescent magnetite/poly(DL-lactic acid-co- $\alpha, \beta$-malic acid) composite nanoparticles for stem cell labeling. Biomaterials. 2010; (13): 3502-11. DOI: 10.1016/j.biomaterials.2010.01.081.

15. Song $\mathrm{M}$, Moon WK, Kim $\mathrm{Y}$ et al. Labeling Efficacy of Superparamagnetic Iron Oxide Nanoparticles to Human Neural Stem Cells: Comparison of Ferumoxides, Monocrystalline Iron Oxide, Cross-linked Iron Oxide (CLIO)- $\mathrm{NH}_{2}$ and tat-CLIO. Korean J Radiol. 2007; (5): 365-71. DOI: 10.3348/kjr.2007.8.5.365.

16. Odabaș S, Sayar F, Güven $G$ et al. Separation of mesenchymal stem cells with magnetic nanosorbents carrying CD105 and CD73 antibodies in flow-through and batch systems. J Chromatogr B. 2008; 861 (1): 74-80. DOI: 10.1016/j.jchromb.2007.11.017.

17. Ito A, Hibino E, Honda H et al. A new methodology of mesenchymal stem cell expansion using magnetic nanoparticle. Biochem Eng J. 2004; 20 (2-3): 119-25. DOI: 10.1016/j.bej.2003.09.018.

18. Hsiao JK, Tai M-F, Chu H-H et al. Magnetic nanoparticle labeling of mesenchymal stem cells without transfection agent: cellular behavior and capability of detection with clinical $1.5 \mathrm{~T}$ magnetic resonance at the single cell level. Magnet Reson Med. 2007: 71724. DOI: $10.1002 / \mathrm{mrm} .21377$.

19. Zhu J, WuX, Zhang HL. Adult Neural Stem Cell Therapy: Expansion In Vitro, Tracking In Vivo and Clinical Transplantation. Curr Drug Targets. 2005; 6 (1): 97-110. DOI: 10.2174/1389450053345055.

20. Petrova EA, Drazhina NP, Semenova EM, Vorobyova SA. Primenenie magnitnyh nanochastic dlja markirovanija mezenhimal'nyh stvolovyh kletok. Vestnik BGU. Serija 2. 2012; (3): 54-9.

21. Drazhina NP, Petrova EA, Semenova EM, Vorobyova SA, avtory. Uchrezhdenie obrazovanija «Belorusskij gosudarstvennyj medicinskij universitet», Uchrezhdenie Belorusskogo gosudarstvennogo universiteta «Nauchno-issledovatel'skij institut fiziko-himicheskih problem», patentoobladateli. Koncentrat dlja poluchenija sredstva vital'noj markirovki mezenhimal'nyh stvolovyh kletok. Patent RB 17804. 15.02.2012.

Amer Chem Soc. 2005; (127): 16090-7. DOI: 10.1021/ja053659j.

10. Bayev VG, Fedotova JA, Vorobyova SA, Svito IA, Ivashkevich OA, Tyutyunnikov SI, Kolobylina NN, Guryeva PV. Mössbauer spectroscopy and magnetometry of FeCo-Ag and FeCo-Au nanocomposites synthesized by a redox-transmetalation method. Materials Chemistry and Physics 2018; (216): 349-53. DOI: 10.1016/j.matchemphys.2018.06.031.

11. Auchynnikava AA, Vorobyova SA, Rzheussky SE. Antimicrobial activity of copper nanoparticles depending on the particles size. Physics, Chemistry and Application of Nanostructures: Proceeding of the International Conference. Nanomeeting-2015; 2015 May; Minsk, Belarus. 480-3.

12. Ржеусский С. Э., Авчинникова Е. А., Воробьева С. А. Нанодиагностика и антимикробные свойства наночастиц меди. Вестник фармации. 2014; (3): 62-8.

13. Cen L, Neoh KG, Sun J, Hu F et al. Labeling of Adipose Derived Stem Cells by Oleic Acid Modified Magnetic Nanoparticles. Adv Funct Mater. 2009; (8): 1158-66. DOI: 10.1002/adfm.200801670.

14. Wang L, Neoh K-G, Kang E-T et al. Biodegradable magneticfluorescent magnetite/poly(DL-lactic acid-co- $\alpha, \beta$-malic acid) composite nanoparticles for stem cell labeling. Biomaterials. 2010; (13): 3502-11. DOI: 10.1016/j.biomaterials.2010.01.081.

15. Song $\mathrm{M}$, Moon WK, Kim $\mathrm{Y}$ et al. Labeling Efficacy of Superparamagnetic Iron Oxide Nanoparticles to Human Neural Stem Cells: Comparison of Ferumoxides, Monocrystalline Iron Oxide, Cross-linked Iron Oxide (CLIO)- $\mathrm{NH}_{2}$ and tat-CLIO. Korean J Radiol. 2007; (5): 365-71. DOI: 10.3348/kjr.2007.8.5.365.

16. Odabaș S, Sayar F, Güven G et al. Separation of mesenchymal stem cells with magnetic nanosorbents carrying CD105 and CD73 antibodies in flow-through and batch systems. J Chromatogr B. 
2008; 861 (1): 74-80. DOI: 10.1016/j.jchromb.2007.11.017.

17. Ito A, Hibino $\mathrm{E}, \mathrm{Honda} \mathrm{H}$ et al. A new methodology of mesenchymal stem cell expansion using magnetic nanoparticle. Biochem Eng J. 2004; 20 (2-3): 119-25. DOI: 10.1016/j.bej.2003.09.018.

18. Hsiao JK, Tai M-F, Chu H-H et al. Magnetic nanoparticle labeling of mesenchymal stem cells without transfection agent: cellular behavior and capability of detection with clinical 1.5 T magnetic resonance at the single cell level. Magnet Reson Med. 2007: $717-$ 24. DOI: $10.1002 / \mathrm{mrm} .21377$.

19. Zhu J, WuX, Zhang HL. Adult Neural Stem Cell Therapy: Expansion In Vitro, Tracking In Vivo and Clinical Transplantation. Curr Drug Targets. 2005; 6 (1): 97-110. DOI: 10.2174/1389450053345055.
20. Петрова Е. А., Дражина Н. П., Семенова Е. М., Воробьева С. А. Применение магнитных наночастиц для маркирования мезенхимальных стволовых клеток. Вестник БГУ. Серия 2. 2012; (3): 54-9.

21. Дражина Н. П., Петрова Е. А., Семенова Е. М., Воробьева С. А., авторы. Учреждение образования «Белорусский государственный медицинский университет», Учреждение Белорусского государственного университета «Научноисследовательский институт физико-химических проблем», патентообладатели. Концентрат для получения средства витальной маркировки мезенхимальных стволовых клеток. Патент РБ 17804. 15.02.2012. 